\title{
Protein Phosphorylation in Rhodomicrobium vannielii
}

\author{
By ANDREW M. TURNER AND NICHOLAS H. MANN* \\ Department of Biological Sciences, University of Warwick, Coventry CV4 7AL, UK
}

(Received 23 May 1986; revised 18 July 1986)

\begin{abstract}
Analysis of cell extracts of Rhodomicrobium vannielii continuously labelled with [ $\left.{ }^{32} \mathrm{P}\right]$ orthophosphate revealed that at least 25 polypeptides were phosphorylated, including abundant species of $M_{\mathrm{r}} 88000,66000,55000$ and 12700 , and that the phosphate groups were ester-linked to serine, threonine and tyrosine. Pulse labelling with [ $\left.{ }^{32} \mathrm{P}\right]$ orthophosphate indicated that the protein phosphorylation profile was dependent upon the growth stage of the culture. Comparison of phosphopolypeptide profiles of reproductive and swarmer cells suggested that protein phosphorylation was drastically reduced in the swarmer cell. However, during the course of differentiation phosphopolypeptides became increasingly abundant, particularly two species of $M_{\mathrm{r}} 55000$ and 86000 . Although protein kinase activities could be detected in vitro, there was little similarity between the in vitro pattern of phosphorylated polypeptides and that obtained in vivo.
\end{abstract}

\section{INTRODUCTION}

Protein phosphorylation has long been recognized as an important regulatory phenomenon in eukaryotes; however, until recently its occurrence in prokaryotes was controversial. The first conclusive demonstration of protein kinase activity, unrelated to phage infection, in a prokaryotic organism was achieved with Salmonella typhimurium (Wang \& Koshland, 1978). Since then it has been shown that in Escherichia coli more than 40 proteins, including possibly RNA polymerase, are subject to phosphorylation (Enami \& Ishihama, 1984) and that phosphorylation of proteins occurs primarily at serine residues and occasionally at threonine (Mannai \& Cozzone, 1983), though phosphotyrosine is found in a polypeptide of $M_{\mathrm{r}} 54500$ (Cortay et al., 1986). The occurrence of protein phosphorylation has now been demonstrated in several diverse species of bacteria including Rhodospirillum rubrum (Holuigue et al., 1985), Sulfolobus acidocaldarious (Skorko, 1984), Streptococcus pyogenes (Deutscher \& Saier, 1983), Myxococcus xanthus (Komano et al., 1982), Clostridium sphenoides (Antranikian et al., 1985), Synechococcus 6301 (Allen et al., 1985) and Rhodocyclus gelatinosus (Averhoff et al., 1986). Consequently, it seems likely that protein phosphorylation is a universal phenomenon in prokaryotes. In only one case has the metabolic role of protein phosphorylation been clearly defined: in $E$. coli the acetate-dependent attenuation of isocitrate dehydrogenase activity is mediated by phosphorylation of the enzyme (see Nimmo, 1984).

In this laboratory we have been concerned with demonstrating the occurrence of protein phosphorylation in the purple non-sulphur bacterium Rhodomicrobium vannielii and investigating its role in the differentiation of the swarmer cell of this species. $R m$. vannielii exhibits a polymorphic cell cycle. In batch culture it exists as small ovoid cells connected by filaments (prosthecae) which may be branched to form ramifying multicellular arrays. In the late exponential phase of growth, peritrichously flagellate swarmer cells are formed at the filament tips and subsequently released. These swarmer cells are reproductively inactive and exhibit diminished metabolic activity; they have been described as growth precursor cells (Dow et al., 1983). Upon an increase in light intensity, under favourable nutrient conditions, the swarmer cells go through an obligate morphogenetic sequence, during which they become reproductively mature and which culminates in cell division (see Whittenbury \& Dow, 1977). 


\section{METHODS}

Materials. $O$-Phospho-L-serine, $O$-phospho-L-tyrosine, $O$-phospho-DL-threonine, $\mathrm{NaF}, m$-aminophenylboronic acid, DNAase, RNAase A, RNAase $T_{1}$ and protease type XI(K) were obtained from Sigma. Acrylamide and PAGE blue 83 were obtained from BDH and were of Electran grade. Other gel components were from Bio-Rad and were of electrophoresis purity. Protein standards for $M_{\mathrm{r}}$ estimations were obtained from Pharmacia. Acidfree, carrier-free [32 P]orthophosphate and [ $\left.\gamma^{32} \mathrm{P}\right]$ ATP (sp. act. $5000 \mathrm{Ci} \mathrm{mmol}^{-1} ; 185 \mathrm{TBq} \mathrm{mmol}^{-1}$ ) were obtained from Amersham.

Culture conditions, radioactive labelling and preparation of swarmer cell cultures. $R m$. vannielii $\mathrm{Rm} 5$ was grown anaerobically in the light at $30^{\circ} \mathrm{C}$ in pyruvate/malate medium (Whittenbury \& Dow, 1977) except that the phosphate concentration was reduced to $0.625 \mathrm{~mm}$. Cultures were continuously or pulse-labelled with [32P]orthophosphate at concentrations of $10-50 \mu \mathrm{Ci} \mathrm{ml}^{-1}$. For phosphoamino acid analysis $R m$. vannielii was grown in the same medium except that it lacked all phosphate apart from that provided by the 1 in 50 inoculum and contained $50 \mathrm{mM}$-HEPES pH $6 \cdot 8$.

Homogeneous populations of swarmer cells were prepared by the filtration technique of Whittenbury \& Dow (1977). Vegetative cells in multicellular arrays were separated from swarmer cells by centrifuging five times at $1200 \mathrm{~g}$ for $2 \mathrm{~min}$.

Preparation of cell-free extracts and in vitro labelling. Cells were harvested by centrifugation at $40000 \mathrm{~g}$ for $30 \mathrm{~min}$, resuspended in a minimal volume of kinase buffer $\left(50 \mathrm{mM}-\mathrm{Tris} / \mathrm{HCl} \mathrm{pH} 7.5,10 \mathrm{mM}-\mathrm{MgCl}_{2}, 5 \mathrm{mM}-2-\right.$ mercaptoethanol) and sonicated five times for $20 \mathrm{~s}$ in a methanol/ice bath at an amplitude of $24 \mu \mathrm{m}$ peak to peak with a $1 \mathrm{~min}$ cooling period between each pulse. Extracts were treated with DNAase $\left(20 \mu \mathrm{g} \mathrm{ml}^{-1}\right)$ and RNAase $\left(20 \mathrm{ug} \mathrm{ml}^{-1}\right)$ for $30 \mathrm{~min}$ prior to removal of particulate material by centrifugation at $38000 \mathrm{~g}$ for $1 \mathrm{~h}$. Protein was then assayed using the Bio-Rad protein assay reagent and samples were diluted to $1 \mathrm{mg}$ protein $\mathrm{ml}^{-1}$ prior to storage at $-70^{\circ} \mathrm{C}$. Protein kinase assays were done by incubating $40 \mu \mathrm{l}$ of sample with $10 \mu 10.5 \mathrm{~mm}$-ATP containing $10 \mu \mathrm{Ci}\left[\gamma^{32} \mathrm{P}\right] \mathrm{ATP}$ at room temperature for $30 \mathrm{~min}$. Reactions were stopped by the addition of an equal volume of $2 \times$ sample buffer (Laemmli, 1970) and boiling for $5 \mathrm{~min}$. Samples were analysed on SDS $10-30 \%(\mathrm{w} / \mathrm{v})$ polyacrylamide gels.

Sample preparation for SDS-PAGE and two-dimensional PAGE. To prepare samples for one-dimensional SDSPAGE, NaF was added to cultures to a final concentration of $100 \mathrm{mM}$ before harvesting and the cells were collected by centrifugation at $38000 \mathrm{~g}$ for $20 \mathrm{~min}$. The cells were washed twice with $20 \mathrm{~mm}-\mathrm{Tris} / \mathrm{HCl} \mathrm{pH} \mathrm{7.4}$, $50 \mathrm{mM}-\mathrm{NaF}$, and twice with ice-cold acetone. The pellet was dried and the protein solubilized by heating at $100^{\circ} \mathrm{C}$ in $100 \mu \mathrm{l}$ sample buffer (Laemmli, 1970). The samples were then incubated with $40 \mu \mathrm{g}$ RNAase A overnight at $20^{\circ} \mathrm{C}$.

Extracts for analysis by two-dimensional PAGE were prepared by harvesting cells and resuspending them in $60 \mathrm{~mm}$-Tris, $30 \mathrm{mM}-\mathrm{H}_{3} \mathrm{PO}_{4}, \mathrm{pH} 6.9$ ( $\mathrm{pH}$ adjusted with $\mathrm{NaOH}$ ). The cells were disrupted by sonication and the sonicate was incubated with DNAase $\left(20 \mu \mathrm{g} \mathrm{ml}^{-1}\right)$ and RNAase A $\left(20 \mu \mathrm{g} \mathrm{ml}^{-1}\right)$ before centrifugation at $12000 \mathrm{~g}$ for $5 \mathrm{~min}$. Samples were used immediately for analysis.

$P A G E$ and autoradiography. Samples were analysed on $10-30 \%(\mathrm{w} / \mathrm{v})$ polyacrylamide exponential gradient gels and protein bands were visualized by staining with PAGE blue 83 . Gels were then destained for $30 \mathrm{~min}$ in $10 \%$ (w/v) acetic acid $/ 50 \%(\mathrm{v} / \mathrm{v})$ methanol, treated for $40 \mathrm{~min}$ with $16 \%(\mathrm{w} / \mathrm{v})$ trichloroacetic acid (TCA) at $95{ }^{\circ} \mathrm{C}$ as described by Mannai \& Cozzone (1982) and then washed overnight in three changes of $5 \%(\mathrm{w} / \mathrm{v})$ TCA $/ 50 \mathrm{mM}$ $\mathrm{Na}_{2} \mathrm{HPO}_{4} / 45 \%$ (v/v) methanol. The gels were finally washed in $1 \%(\mathrm{v} / \mathrm{v})$ glycerol $/ 5 \%(\mathrm{w} / \mathrm{v}) \mathrm{TCA} / 50 \mathrm{~mm}$ $\mathrm{Na}_{2} \mathrm{HPO}_{4} / 45 \%(\mathrm{v} / \mathrm{v})$ methanol for $1 \mathrm{~h}$ and dried under vacuum. Radioactive bands were visualized by autoradiography with Fuji RX X-ray film and Dupont Cronex Lightning Plus intensifying screens for 2-14 d at $-70^{\circ} \mathrm{C}$.

Two-dimensional electrophoresis was done using a non-denaturing gel in the first dimension, adapted by $\mathrm{D}$. Porter (personal communication) from a system described by Sargent \& George (1975), and by SDS-PAGE in the second dimension. Samples were analysed in the first dimension by electrophoresis on a 5-15\% (w/v) exponential non-denaturing polyacrylamide gradient gel. The effects of charge on native protein mobility were minimized by electrophoresing until protein migration was halted by the increasing acrylamide concentration. The gel was then stained, dried and autoradiographed. Tracks were then cut from the dried gel and rehydrated in $40 \%(\mathrm{v} / \mathrm{v})$ methanol $/ 7 \%(\mathrm{v} / \mathrm{v})$ acetic acid. They were then equilibrated for SDS-PAGE by soaking twice for $15 \mathrm{~min}$ each in $62 \mathrm{~mm}-\mathrm{Tris} / \mathrm{HCl}(\mathrm{pH} 6.8), 2 \%(\mathrm{w} / \mathrm{v}) \mathrm{SDS}$ and $0.5 \%(\mathrm{v} / \mathrm{v}) 2$-mercaptoethanol. The rehydrated gels were then laid onto a flat stacking gel of a SDS $10-30 \%(\mathrm{w} / \mathrm{v})$ polyacrylamide gel and sealed in with $1 \%(\mathrm{w} / \mathrm{v})$ agarose in equilibration buffer before electrophoresis in the second dimension.

Preparation and analysis of phosphoamino acids. $\left.{ }^{[32} \mathrm{P}\right]$ Orthophosphate $(5 \mathrm{mCi})$ was added to a $4 \mathrm{ml}$ culture in early exponential phase and the cells were harvested in late exponential phase by centrifugation for $1 \mathrm{~min}$ in an Eppendorf microcentrifuge. The cells were resuspended in $750 \mu \mathrm{l}$ DNAase buffer $(20 \mathrm{mM}-\mathrm{Tris} / \mathrm{HCl} \mathrm{pH} 7.5$, $10 \mathrm{mM}-\mathrm{MgCl}_{2}, 2 \mathrm{mM}-\mathrm{CaCl}_{2}, 1 \mathrm{mM}-2$-mercaptoethanol) and disrupted ultrasonically. The sonicate was incubated with $30 \mu \mathrm{g}$ DNAase, 3.6 $\mu \mathrm{g}$ RNAase $\mathrm{T}_{1}$ and $60 \mu \mathrm{g}$ RNAase $\mathrm{A}$ for $1 \mathrm{~h}$ at $30^{\circ} \mathrm{C}$ and then extracted once with $750 \mu \mathrm{l}$ 


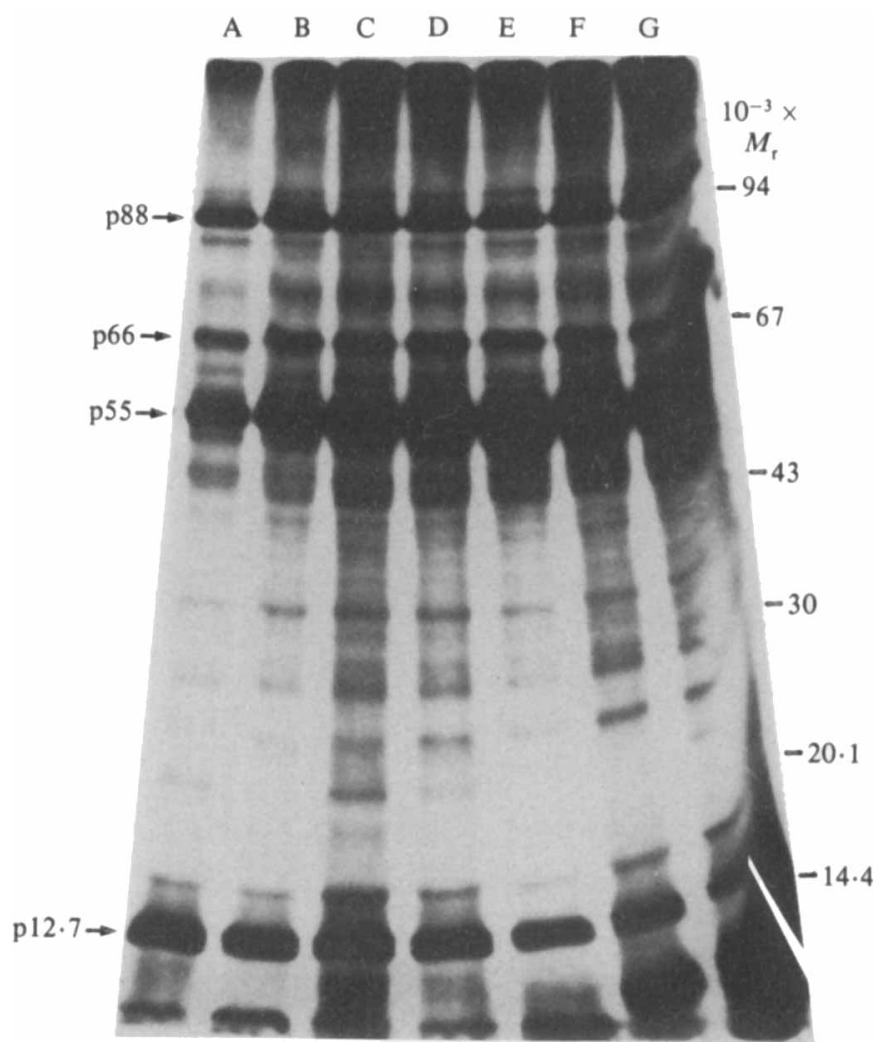

Fig. 1. Autoradiograph of an electrophoretogram of polypeptides extracted from cells at different stages of batch culture, continuously labelled with [ ${ }^{32} \mathrm{P}$ ]orthophosphate. Lanes: $\mathrm{A}$ and $\mathrm{B}$, early exponential phase; $C$ and $D$, mid-exponential phase; $E$, late exponential phase; $F$, early stationary phase; $G$, late stationary phase. Positions of the major phosphorylated polypeptides are shown on the left $\left(10^{-3} \times M_{\mathrm{r}}\right.$, prefixed 'p'); positions of $M_{\mathrm{r}}$ standards are shown on the right.

chloroform/methanol $(1: 1, v / v)$. Sufficient $50 \%(w / v)$ TCA was added to the remaining aqueous phase to give a final concentration of $10 \%(\mathrm{w} / \mathrm{v})$ TCA. The sample was vortexed, kept on ice for $10 \mathrm{~min}$, and TCA-insoluble material was then collected by centrifugation in an Eppendorf microcentrifuge. The proteins in the sample were solubilized by heating at $100^{\circ} \mathrm{C}$ in $400 \mu \mathrm{l}$ sample buffer for $5 \mathrm{~min}$ and any insoluble material was removed by centrifugation. Ice-cold $1 \mathrm{M}-\mathrm{KCl}(100 \mu \mathrm{l})$ was then added to the supernatant to precipitate protein-SDS complexes and after $10 \mathrm{~min}$ on ice the precipitated proteins were collected by centrifugation. The protein pellet was washed once with $10 \mathrm{mM}$-Tris/HCl pH 7.5, $1 \mathrm{mM}$-EDTA, $100 \mathrm{mM}-\mathrm{KCl}$, once with $95 \%$ (v/v) ethanol and once with ice-cold acetone before drying. The proteins were then resuspended in $200 \mu 16 \mathrm{M}-\mathrm{HCl}$ and hydrolysed at $121^{\circ} \mathrm{C}$ for $3 \mathrm{~h}$. The products of hydrolysis were analysed by high-voltage two-dimensional thin-layer electrophoresis by the method of Mannai \& Cozzone (1982) using HPTLC cellulose plates (BDH). Standards consisting of the $O$-phosphorylated derivatives of serine, threonine and tyrosine were added to the hydrolysate before analysis and subsequently visualized by spraying with $0.5 \%(\mathrm{w} / \mathrm{v})$ ninhydrin in acetone. The plates were autoradiographed for $7-14 \mathrm{~d}$ and the positions of the radioactive spots were compared to those of the standards. The relative amounts of the different phosphoamino acids in the hydrolysate were quantified by scraping the areas of the plate corresponding to the standards into scintillation vials, overlaying with $5 \mathrm{ml}$ Beckman EP scintillation cocktail, and counting in an LKB Minibeta scintillation counter.

\section{RESULTS}

To establish whether phosphorylated proteins could be detected in $R m$. vannielii, cells were continuously labelled with [ $\left.{ }^{32} \mathrm{P}\right]$ orthophosphate and samples were withdrawn from the culture at intervals during growth. The size of sample was calculated to yield a constant amount of cellular 


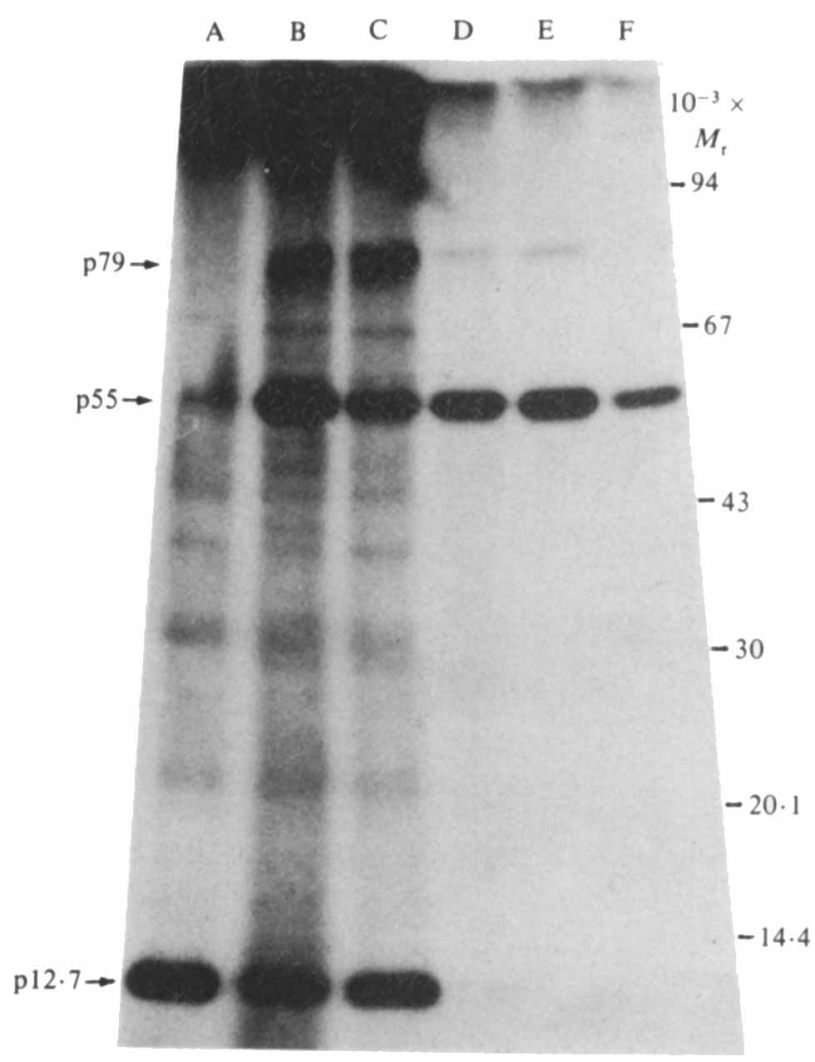

Fig. 2. Autoradiograph of an electrophoretogram of polypeptides extracted from cells pulse-labelled with $\left[{ }^{32} \mathrm{P}\right]$ orthophosphate at different stages of batch culture. Samples were diluted back to the same $\mathrm{OD}_{540}(0.285)$ with filtered medium from the culture. Lanes: A, early exponential phase; B and C, midexponential phase; D, late exponential phase; E, early stationary phase; F, late stationary phase.

material (3.5 $\mathrm{OD}_{540}$ units). The cell extracts were analysed by SDS-PAGE and autoradiography. From the pattern of phosphopolypeptides from a continuously labelled culture, it is clear that at least 25 distinct phosphorylated species were present, with particularly abundant species of $M_{\mathrm{r}}$ $88000,66000,55000$ and 12700 (Fig. 1). The profile was unaffected by the stage of growth of the culture. To establish whether certain polypeptides were phosphorylated only at specific stages of growth, pulse-labelling experiments with [ $\left.{ }^{32} \mathrm{P}\right]$ orthophosphate were done in two ways. The first method of pulse labelling was to remove samples at different stages of growth from a single culture and to dilute them back to the same $\mathrm{OD}_{540}$ with filtered medium taken from the same culture prior to incubation with $\left[{ }^{32} \mathrm{P}\right]$ orthophosphate for $2 \mathrm{~h}$. Thus the cells in each sample were exposed to the same incident light intensity but the concentrations of nutrients would be characteristic of the particular stage of growth. Three major species exhibited a growth-stagedependent pattern of phosphorylation (Fig. 2). The $M_{\mathrm{r}} 12700$ species was phosphorylated only during early and mid-exponential phase, the $M_{\mathrm{r}} 79000$ species was detected primarily during mid-exponential phase and the $M_{\mathrm{r}} 55000$ species became increasingly abundant during the later stages of growth and entry into stationary phase. Secondly, a series of four cultures at different stages of growth were each pulse-labelled for $2 \mathrm{~h}$ with $\left[{ }^{32} \mathrm{P}\right]$ orthophosphate. With this method we detected essentially the same pattern of phosphopolypeptides as with the first method except that the polypeptide specifically labelled during the mid-exponential phase of growth had an apparent $M_{\mathrm{r}}$ of 92000 (data not shown).

The hot acid treatment of the polyacrylamide gels used to detect the phosphopolypeptides confirmed that we were detecting ester-linked phosphopolypeptides since amidophosphates and acyl-linked phosphates are unstable under these conditions; the radio-labelled species were also 


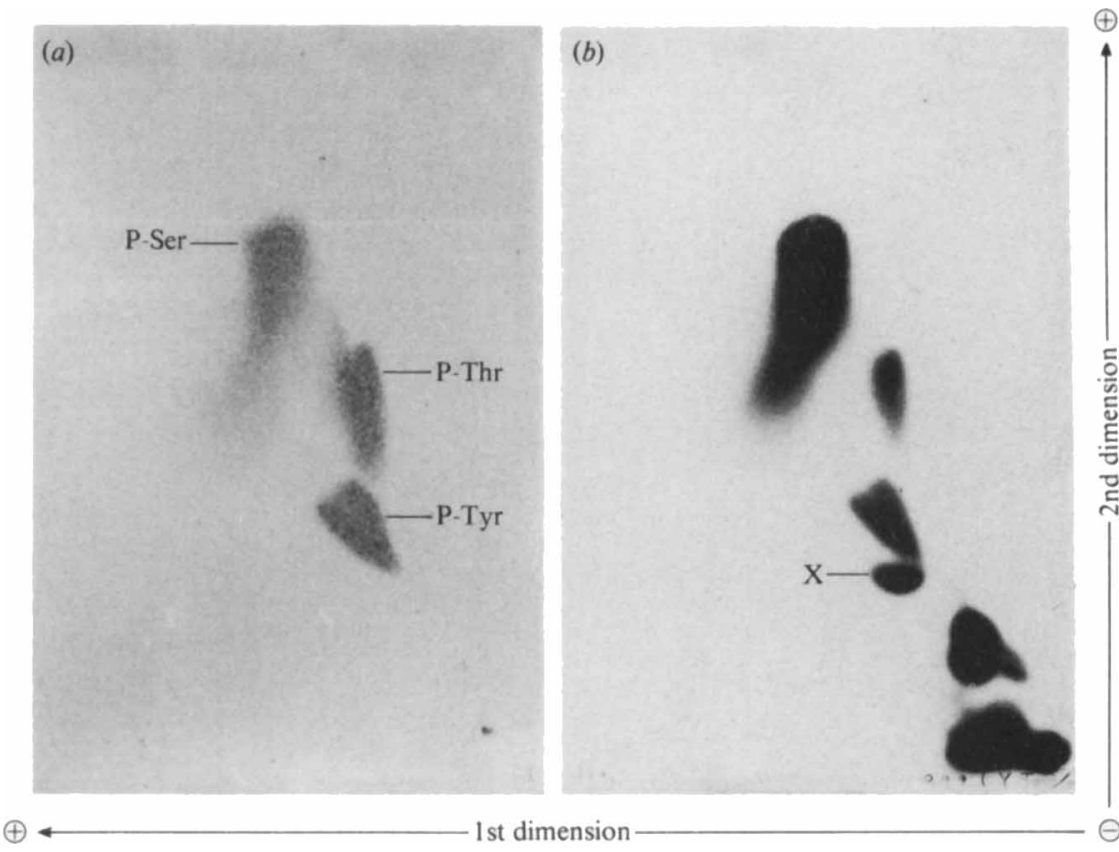

Fig. 3. Identification of phosphoamino acids. Protein from a late exponential phase culture continuously labelled with $\left[{ }^{32} \mathrm{P}\right]$ orthophosphate was hydrolysed and individual phosphoamino acids were identified by high-voltage thin-layer electrophoresis with authentic phosphoamino acid standards. (a) Ninhydrin-stained thin-layer plate; $(b)$ autoradiograph of the thin-layer plate. The positions of the phosphoamino acid standards phosphoserine (P-Ser), phosphothreonine (P-Thr) and phosphotyrosine (P-Tyr) are indicated. $\mathrm{X}$ is an unidentified labelled spot that migrated close to phosphotyrosine.

susceptible to degradation by protease $\mathrm{K}$. The individual phosphoamino acids were identified (Fig. 3) by two-dimensional thin-layer electrophoresis as phosphoserine, phosphothreonine and phosphotyrosine and were quantified $(73 \%, 13.5 \%$ and $13.5 \%$ respectively) by scraping off the appropriate areas of the thin-layer plate and measuring the relative amounts of material by liquid scintillation counting. A fourth labelled spot (marked $\mathrm{X}$ in Fig. $3 b$ ) was detected which migrated close to phosphotyrosine, though did not overlap with it.

To establish whether the phosphopolypeptides we were detecting on denaturing gels were actually components of larger protein complexes, an extract of continuously labelled cells harvested at the late exponential phase of growth was analysed by two-dimensional polyacrylamide gel electrophoresis with a non-denaturing gel in the first dimension and a denaturing polyacrylamide gradient gel in the second dimension. The results (not shown) suggested that the majority of phosphopolypeptides, including the abundant species of $M_{\mathrm{r}}$ 55000 , existed in a complex (or complexes) with an apparent $M_{\mathrm{r}}$ of 320000 . Furthermore, we established that several of the phosphorylated components of this complex appeared to be sensitive to degradation by serine proteases by carrying out a similar two-dimensional analysis of material isolated in the presence of $m$-aminophenylboronic acid, a potent serine protease inhibitor (Philipp \& Bender, 1971).

The fact that certain polypeptides were phosphorylated at particular stages of growth suggested that the phosphopolypeptide profile of the swarmer cell might be different from that of the reproductive cell. The different cell types were purified from a culture which had been continuously labelled with $\left[{ }^{32} \mathrm{P}\right]$ orthophosphate and the distribution of phosphopolypeptides was then determined. Phosphopolypeptides were not detected in the undifferentiated swarmer cell fraction (data not shown). Pulse labelling of a homogeneous population of swarmer cells at different stages of differentiation (Fig. 4) confirmed that phosphorylated species could not be readily detected in the swarmer prior to differentiation; a species of $M_{\mathrm{r}} 55000$ and one of $M_{\mathrm{r}}$ 


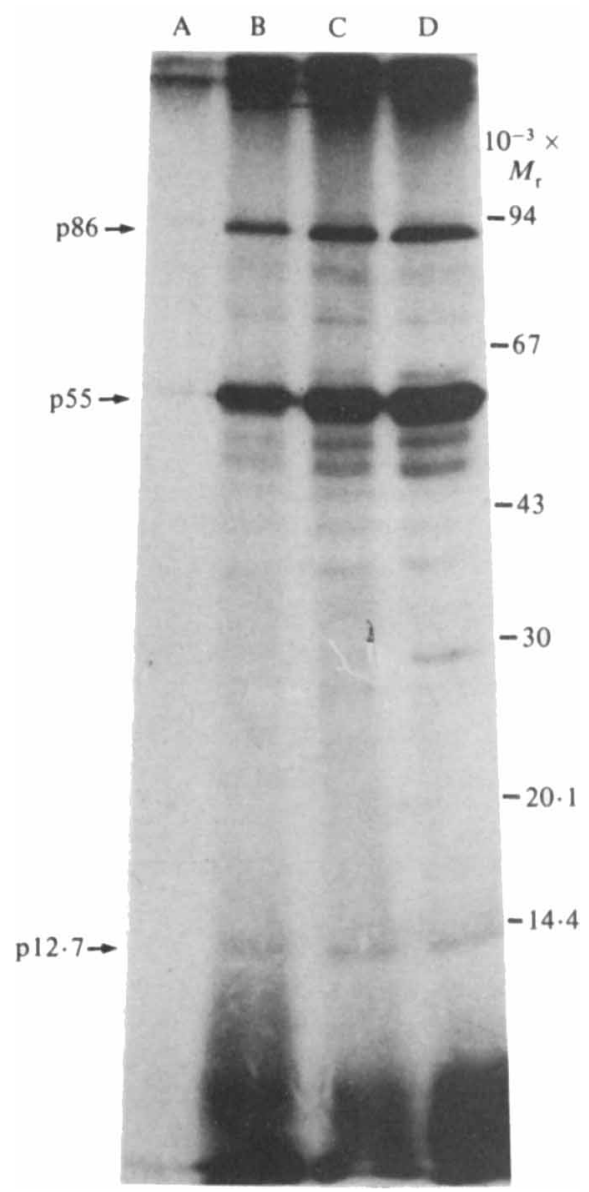

Fig. 4. Autoradiograph of an electrophoretogram of polypeptides extracted from swarmer cells pulse-labelled with $\left[{ }^{32} \mathrm{P}\right]$ orthophosphate at different stages of differentiation. Lanes: A, undifferentiated swarmer cells; B, $2 \mathrm{~h}$ differentiation; $\mathrm{C}, 4 \mathrm{~h}$ differentiation; $\mathrm{D}, 6 \mathrm{~h}$ differentiation.

86000 could just be detected. However, as differentiation proceeded the $M_{\mathrm{r}} 55000$ and 86000 species became increasingly abundant and several minor species appeared. When swarmer cells were isolated from a culture which had been continuously labelled with [ ${ }^{32} \mathrm{P}$ ]orthophosphate a similar pattern was observed (data not shown). The $M_{\mathrm{r}} 55000$ polypeptide could just be detected in the swarmer cell prior to differentiation, but became increasingly abundant during the course of a differentiation as did the $M_{\mathrm{r}} 12700$ species.

Protein kinase activities were also detected in vitro (Fig. 5, lanes A-D). Cell extracts from swarmer cells harvested at different stages of differentiation catalysed the phosphorylation of three polypeptides $\left(M_{\mathrm{r}} 60000,57000\right.$ and 15000). However, the polypeptides phosphorylated in vitro by cell extracts from swarmer cells were not of precisely the same size as those detected by pulse-labelling of swarmer cells with [ $\left.{ }^{32} \mathrm{P}\right]$ orthophosphate (Fig. 5, lanes F-I). Cell extracts from swarmer cells which had been differentiating for $6 \mathrm{~h}$ catalysed the phosphorylation of three additional polypeptides $\left(M_{\mathrm{r}} 50000,42000\right.$ and 29000) compared to extracts from earlier stages of differentiation.

\section{DISCUSSION}

One dimensional electrophoresis of cell extracts of $R m$. vannielii labelled with [ ${ }^{32} \mathrm{P}$ ]orthophosphate clearly revealed the presence of at least 25 phosphopolypeptides, which probably represents an underestimate of the total number in the cell. Three particularly abundant phosphopolypeptides exhibited a growth-stage-dependent pattern of phosphorylation. The variations in the apparent $M_{\mathrm{r}}$ of the largest of these abundant species may indicate that its 


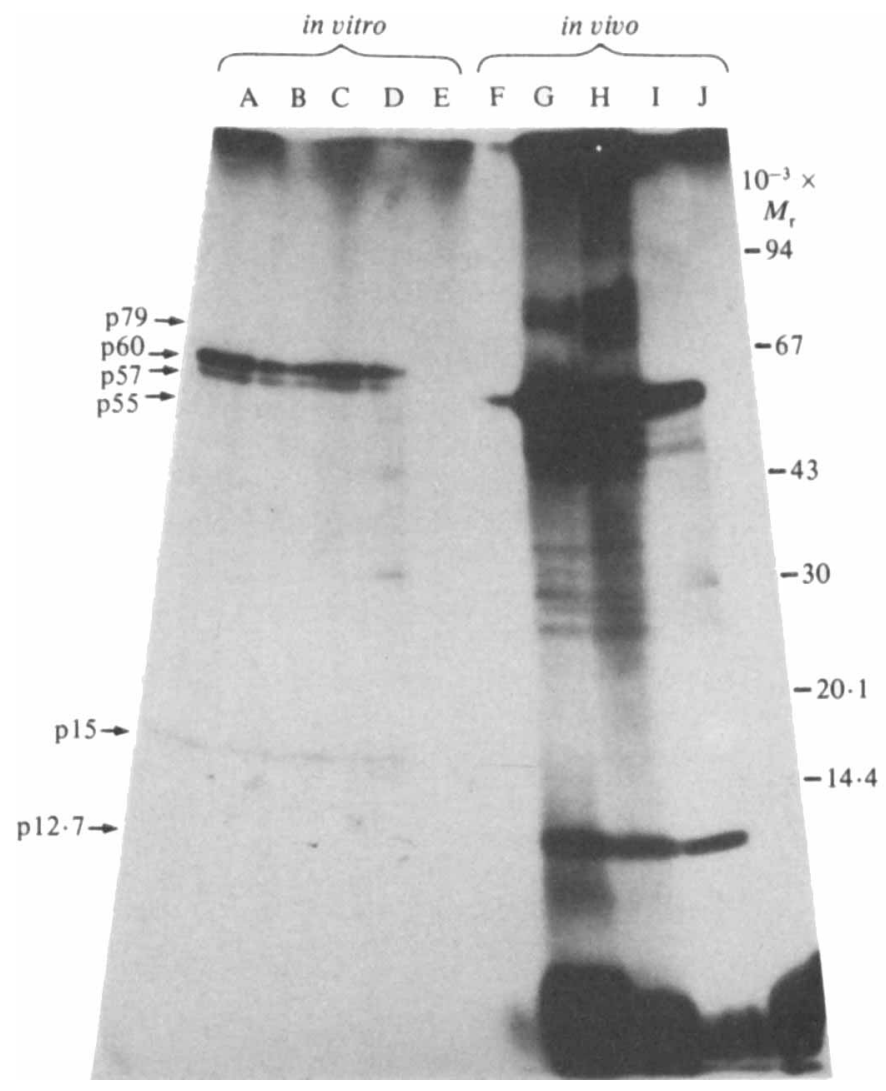

Fig. 5. Autoradiograph of an electrophoretogram of polypeptides phosphorylated in vitro using [ $\gamma$ ${ }^{32}$ P]ATP and polypeptides phosphorylated in vivo extracted from swarmer cells pulse-labelled with [ ${ }^{32} \mathrm{P}$ ]orthophosphate at different stages of differentiation. Lanes $\mathrm{A}-\mathrm{D}$, in vitro protein kinase labelled extracts from swarmer cells at $0,2,4$ and $6 \mathrm{~h}$ of differentiation, respectively; lane $\mathrm{E}$, protease $\mathrm{K}$ treated in vitro labelled extract. Lanes F-I, polypeptides from swarmer cells pulse-labelled at $0,2,4$ and $6 \mathrm{~h}$ of differentiation, respectively; lane $\mathrm{J}$, protease $\mathrm{K}$ treated pulse-labelled sample.

mobility in SDS-gels varies with the extent of its phosphorylation, or that there is more than one species in this $M_{\mathrm{r}}$ range, only one of which is phosphorylated under the different experimental conditions. At present we cannot distinguish between these two possibilities. As yet there is no direct information as to the function of any of the phosphoproteins. However, the species of $M_{\mathrm{r}}$ 12700 might be a component of the light-harvesting complex. In $R \mathrm{~m}$. vannielii the four polypeptides associated with light-gathering pigment complexes have $M_{\mathrm{r}}$ values of 11000 14000 (Kelly \& Dow, 1985). Allen et al. (1985) have shown in the cyanobacterium Synechococcus 6301 that there was a light-dependent phosphorylation of a polypeptide of $M_{\mathrm{r}} 15000$ which was thought to be the antenna chlorophyll-binding protein of photosystem II. Additionally, Holuigue et al. (1985) have demonstrated the in vitro phosphorylation of a polypeptide of $M_{\mathrm{r}}$ 15000 which comigrates with the apoprotein of the light-harvesting chlorophyll-protein complex. Finally, in Rhodospirillum rubrum a polypeptide identified as the $M_{\mathrm{r}} 13000 \mathrm{~B} 880$-alpha subunit of the light-harvesting pigment-protein complex was found to be specifically phosphorylated under cooperative photosynthetic conditions (Holmes \& Allen, 1986). We have observed similarly that the $M_{\mathrm{r}} 12700$ polypeptide was actively phosphorylated only when the culture was not light-limited. Preliminary immunoprecipitation experiments with antiserum raised against purified RNA polymerase from $R m$. vannielii suggest that at least two polypeptides associated with RNA polymerase may also be phosphorylated (unpublished results). 
Phosphoamino acid analysis revealed that phosphoserine was the predominant species $(73 \%)$, although phosphothreonine $(13.5 \%)$ and phosphotyrosine $(13.5 \%)$ were also present. A fourth unidentified labelled spot migrating close to phosphotyrosine was detected; a similarly migrating species was detected by Mannai \& Cozzone (1983) in extracts from salt-washed ribosomes of $E$. coli. The presence of such large amounts of phosphotyrosine in extracts of $R m$. vannielii contrasts with $E$. coli, in which phosphotyrosine is a very minor component (Mannai \& Cozzone, 1983), occurring almost exclusively in the ribosomal/membrane fraction and associated with a polypeptide of $M_{\mathrm{r}} 54500$ (Cortay et al., 1986). However, in Rhodospirillum rubrum phosphotyrosine accounts for $38 \%$ of total phosphoamino acids and is also predominantly associated with the ribosomal/membrane fraction (Holuigue et al., 1985).

Although we were able to detect in vitro protein kinase activities, the major phosphorylated species $\left(M_{\mathrm{r}} 60000,57000\right.$ and 15000$)$ did not correspond to the most abundant species found in vivo $\left(M_{\mathrm{r}} 79000,55000\right.$ and 12700). This, and the presence of detectable kinase activities within undifferentiated swarmer cells, which contain insignificant amounts of phosphopolypeptides, deserve further investigation.

This research was supported by a postgraduate studentship awarded to A. M. T. by the Science and Engineering Research Council.

\section{REFERENCES}

Allen, J. F., SANDers, C. E. \& Holmes, N. G. (1985). Correlation of membrane protein phosphorylation with excitation energy distribution in the cyanobacterium Synechococcus 6301. FEBS Letters 193, 271275.

antranikian, G., Herzberg, C. \& Gottschalk, G. (1985). In vivo phosphorylation of proteins in Clostridium sphenoides. FEMS Microbiology Letters 27, 135-138.

Averhoff, B., ANtranikian, G. \& Gottschalk, G. (1986). Phosphorylation of proteins in Rhodocyclus gelatinosus. FEMS Microbiology Letters 33, 299-304.

Cortay, J. C., Duclos, B. \& Cozzone, A. J. (1986). Phosphorylation of an Escherichia coli protein at tyrosine. Journal of Molecular Biology 187, 303-308.

DeUTSChER, J. \& SAIER, M. H. (1983). ATP-dependent protein kinase-catalysed phosphorylation of a seryl residue in $\mathrm{HPr}$, a phosphate carrier protein of the phosphotransferase system in Streptococcus pyogenes. Proceedings of the National Academy of Sciences of the United States of America 80, 67906794.

Dow, C. S., WhitTenbury, R. \& CARR, N. G. (1983). The 'shut down' or 'growth precursor' cell - an adaptation for survival in a potentially hostile environment. Symposia of the Society for General Microbiology 34, 187-247.

Enami. M. \& Ishihama, A. (1984). Protein phosphorylation in Escherichia coli and purification of a protein kinase. Journal of Biological Chemistry 259, 526533.

Holmes, N. G. \& Allen, J. F. (1986). Protein phosphorylation as a control for excitation energy transfer in Rhodospirillum rubrum. FEBS Letters $\mathbf{2 0 0}$, 144-148.

Holuigue, L., Lucero, H. A. \& Vallejos, R. H. (1985). Protein phosphorylation in the photosynthetic bacterium Rhodospirillum rubrum. FEBS Letters 181, 103-107.

Kelly, D. J. \& Dow, C. S. (1985). Isolation, characterization and topographical relationships of pigment-protein complexes from membranes of Rhodomicrobium vannielii. Journal of General Microbiology 131, 2941-2952.

Komano, T., Brown, N., Inouye, S. \& Inouye, M. (1982). Phosphorylation and methylation of proteins during Myxococcus xanthus spore formation. Journal of Bacteriology 151, 114-118.

LAEMMLI, U. K. (1970). Cleavage of structural proteins during the assembly of the head of bacteriophage T4. Nature, London 227, 680-685.

Mannai, M. \& Cozzone, A. J. (1982). Endogenous protein phosphorylation in Escherichia coli extracts. Biochemical and Biophysical Research Communications 107, 981-988.

Mannal, M. \& Cozzone, A. J. (1983). Characterization of the amino acids phosphorylated in Escherichia coli proteins. FEMS Microbiology Letters 17,87 91.

Nimmo, H. G. (1984). Control of Escherichia coli isocitrate dehydrogenase: an example of protein phosphorylation in a prokaryote. Trends in Biochemical Sciences 9, 475-478.

Philipp, M. \& Bender, M. L. (1971). Inhibition of serine proteases by aryl boronic acids. Proceedings of the National Academy of Sciences of the United States of America 68, 478-480.

SARGent, J. R. \& GeORge, S. G. (1975). Methods in Zone Electrophoresis. Poole: BDH Ltd.

SKorko, R. (1984). Protein phosphorylation in the archaebacterium Sulfolobus acidocaldarius. European Journal of Biochemistry 145, 617-622.

Wang, J. Y. J. \& Koshland, D. E., JR (1978). Evidence for protein kinase activities in the prokaryote Salmonella typhimurium. Journal of Biological Chemistry 253, 7605-7608.

WhITtEnbURY, R. \& Dow, C. S. (1977). Morphogenesis and differentiation in Rhodomicrobium vannielii and other budding and prosthecate bacteria. Microbiological Reviews 41, 754-808. 